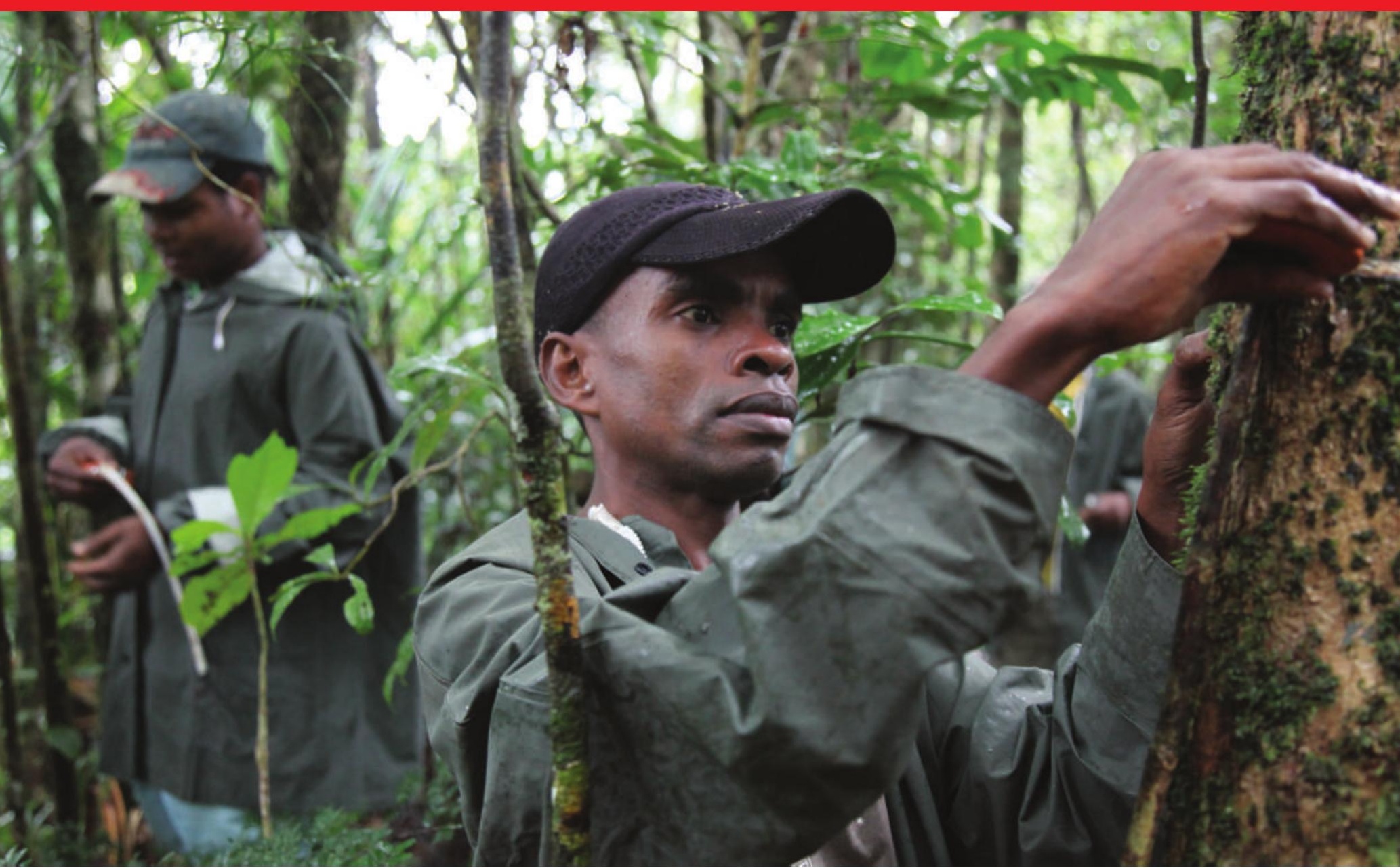

\title{
HOW TO SAVE A FOREST
}

\section{Projects in Madagascar could provide a model for stemming deforestation. But first these efforts must deal with the poverty and political upheaval that threaten forests, reports Anjali Nayar.}

élix Ratelolahy and his team of field researchers are hiking through the dense growth of the Makira forest in northeastern Madagascar. Uapaca trees tower over them, with their spider-leg roots tall enough to walk under. Brilliant white orchids pour out of their perches in the trees. And every so often the leaves above rustle, as googly-eyed lemurs dance among the branches.

Ratelolahy, an ecologist with the Wildlife Conservation Society (WCS), and his team have spent most of the past year in this 5,200-square-kilometre forest to determine how much carbon is stored there. And today, after a three-hour hike up a precipitous slope to their first survey point, the team methodically gets to work setting up circular plots and measuring the diameter of trees (pictured above).

"We record all the numbers - the trees, the dead wood and the leaf litter," says Ratelolahy, looking up from his clipboard. "And then back in the capital, poof, the computer calculates the amount of carbon in the forest."
On these multiple-week traverses through the forest, Ratelolahy has glimpsed much of the region's endemic beauty, such as the leaftailed gecko and the all-white silky sifaka - a type of lemur that is one of the rarest animals in the world. But his missions have also been disturbing, he says. Over the years, Ratelolahy has watched subsistence farmers slash and burn away the margins of the forest to grow rice. And he has come across gangs pillaging the forest for rosewood, ebony and quartz. "It looks as though bombs have fallen on the place," says Ratelolahy about the ransacked areas.

Makira is on the front line of the war being waged to slow global warming. As one of Madagascar's largest forests, it stores - Félix Ratelolahy millions of tonnes of carbon. But
as in most forests in the country, - Félix Ratelolahy millions of tonnes of carbon. But
as in most forests in the country, that carbon is being rapidly released to the
atmosphere as trees are cut down for agriculture, timber, mining and firewood. The WCS, in collaboration with the government and other organizations, is hoping to protect Makira and, at the same time, generate money to support local communities by 'renting' the forest to rich countries.

The idea is that wealthy nations could meet their greenhouse-gas emissions targets in part by buying carbon credits from developing countries such as Madagascar. The poorer nations could earn money by keeping their forests standing, rather than cutting them down (see 'A growing market', page 28).

This strategy, known as reducing emissions from deforestation and forest degradation (REDD), is one of the topics up for discussion at the UN climate-change summit in Copenhagen this December. Countries will negotiate whether REDD should be included in the climate deal that takes over from the Kyoto Protocol when it expires in 2012.

Proponents for REDD say that this mechanism is key to cutting deforestation, which accounts for around $20 \%$ of greenhouse-gas emissions. It is also estimated that REDD could generate billions of dollars each year for forest conservation, far more than is currently spent. Hoping to cash in on the future market, projects have burgeoned around the developing 
world, with those in Madagascar being some of the earliest to take shape. The projects are also helping to establish technical standards and methodologies for carbon accounting.

REDD projects must keep the promised forests standing. To succeed, this means addressing the poverty and political instability in developing countries that often lead to deforestation. These problems are particularly acute in Madagascar, where a coup earlier this year disrupted conservation efforts and raised questions about the future of REDD there.

Non-governmental organizations such as the WCS and Conservation International are working through the turmoil. But even they are worried. "We could have a very difficult time selling carbon if this political situation becomes the norm," says Lisa Gaylord, head of the WCS in Antananarivo, the country's capital. "Why would an investor want to come here?"

\section{Hungry for land}

Madagascar is one of the wealthiest countries in terms of biodiversity, but its people are among the world's poorest. Around $85 \%$ of the population live below the World Bank's $\$ 2$-a-day poverty line and most rely heavily on the country's natural resources.

The hilly countryside is scarred by slashand-burn agriculture, locally known as tavy. Once people fully exploit the fertile river valleys, they head uphill, clearing the forests to cultivate rice, the country's staple food. These rain-fed fields are harvestable for only a few seasons before productivity drops and villagers clear new land for their crops.

Estimates of Madagascar's original forested areas vary widely, but some studies suggest that trees once blanketed $90 \%$ or more of the island. Since aerial photographs of the

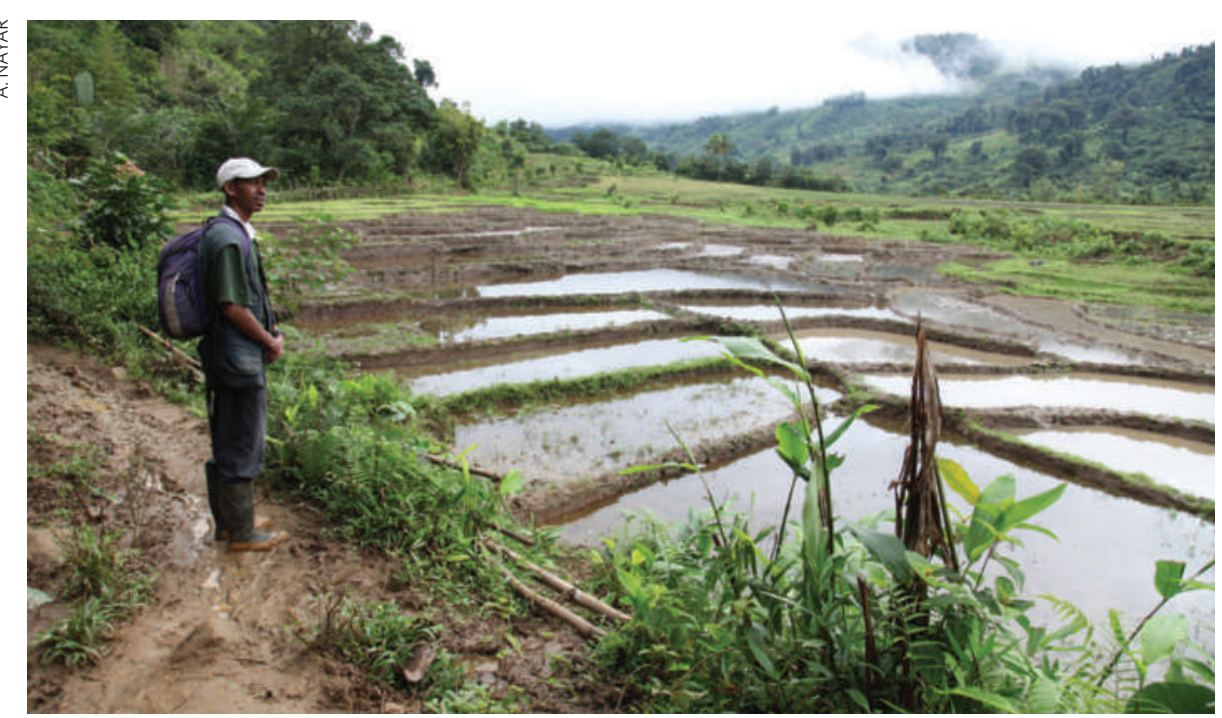

Félix Ratelolahy surveys rice paddies in land once covered by forest.

country were taken in the 1950 s, forests

have decreased by more than $40 \%$ and by about 2005 , they covered only around $15 \%$ of the country.

Over the past two decades, deforestation has been decreasing slowly with the creation of protected areas. Grants from the World Bank and USAID helped Madagascar to become one of the first countries in Africa to develop and implement a national environmental action plan.

By 2000 , the nation had protected 17,000 square kilometres of forest, mainly as national parks. But further expansion of the park system stalled because the funding stream from donors dried up. So, in 2001, the government teamed up with non-governmental organizations and started exploring the idea of selling carbon credits from their forests. "It was clear that there was a carbon market emerging and that avoided deforestation could be a very powerful way of protecting forests in Madagascar," says Frank Hawkins, vice-president for Africa and Madagascar of Conservation International in Washington DC. Hawkins was part of the team that popularized REDD on the island.

The efficacy of a REDD project depends on how much carbon the project will prevent from being released in the absence of protective measures. Calculating that number requires first measuring the current carbon content of a forest - as Ratelolahy and his crew are currently doing - and then projecting future deforestation rates with and without the project in place. The WCS is doing that by using past satellite imagery and making forecasts that account for factors such as the proximity of the

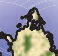

A

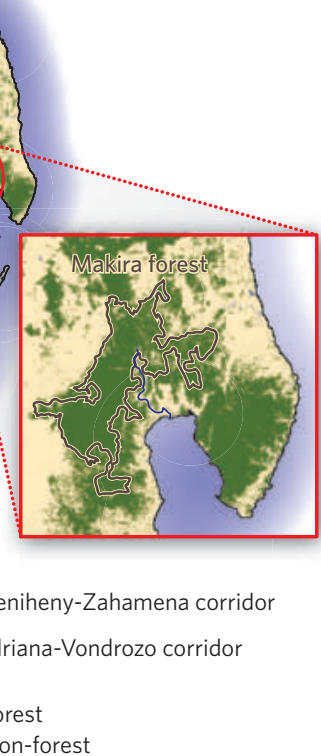

forest to roads and villages.

A study in 2004, conducted in

collaboration with the non-profit organization Winrock International in Little Rock, Arkansas, estimated that the annual rate of deforestation was $0.15 \%$ in Makira. The analysis projected that the rate would rise to $0.2 \%$ a year by 2034 without any intervention. But with the REDD project in place, the deforestation rate would slow to about $0.07 \%$. These preliminary estimates indicated that the 30-year project would avert the release of more than 9 million tonnes of $\mathrm{CO}_{2}$ equivalent, similar to taking 2 million cars off the road in the United States for a year.

Madagascar's other two active REDD projects, in the Ankeniheny-Zahamena and the Fandriana-Vondrozo forest corridors, run by Conservation International, are each projected to prevent emissions of 9 million to 10 million tonnes of $\mathrm{CO}_{2}$ during the same time period.

Together, at a conservative price of US $\$ 5$ per tonne, the REDD schemes in Madagascar could yield up to $\$ 5$ million a year for conservation and community development in the country, about the same as the budget for the national park system. Christopher Holmes, the technical director of the WCS's Madagascar programme, says $50 \%$ of the money from future carbon sales will go to the communities. The rest will be used to cover the costs of running, monitoring and marketing the project.

In the future, the WCS intends to pay the affected communities directly using the carbon money from Makira, but currently there is no distribution mechanism in place. In the meantime, the money will go to health and development projects aimed at reducing poverty. "People are not walking five kilometres to find forest to cut down to plant rice on a $30^{\circ}$ slope because that's the best thing to do," says Holmes. "They are doing it because it's the only thing to do." 
But setting up a REDD project in this remote part of the country is challenging, he says. Without much existing infrastructure there, the WCS has had to establish community organizations and legislative bodies that allow each community to manage their forests.

In Madagascar, the government owns the forest, so the conservation organizations are helping local communities to gain rights over the natural resources through management contracts. But progress is slow. "Some of the communities require two days of driving and three days of hiking on foot to reach," says Holmes. Since the project started in 2003, only one-quarter of Makira's 83 community organizations have signed the contracts with the government.

The contracts give communities legal access to a buffer zone surrounding a core protected area of the forest. When someone in the community wants to build a new house or dugout canoe, that person applies to the community's organization for a permit to use the buffer zone.

Because such agreements effectively limit how much local residents can take from the forest, the WCS is trying to help communities in other ways, through projects to increase rice production and by expanding the country's ecotourism industry into the Makira region. But for now, communities such as the remote village of Andaparaty on the eastern cusp of Makira do not see the potential benefits of carbon sales.

\section{Pressures on the forest}

At sunrise, the riverside village is already bustling. Women are busy laying out a patchwork of woven mats topped with drying rice, beans and vanilla. Later, their meagre produce will be taken downstream to be sold.

Barnety, a man nearing 80, watches the ebb and flow of his village. He is a tangalamena or traditional leader in the community. When he was a boy, he says, there were only a few families in Andaparaty. Now there are hundreds of

\section{A growing market}

Many companies and individuals are going carbon neutral by purchasing credits to offset their emissions. Some of these credits pay for forest protection in tropical countries - essentially keeping the carbon locked in the living trees. Until recently there was a lack of accepted standards to guarantee that such projects result in real emissions reductions, says Toby JansonSmith, senior director for forest carbon markets at Conservation International, which runs forest programmes around the world. "Each project did it in its own way and you had to take the word of the project that they had done a good job."

These credits are traded on a voluntary carbon market, which has grown rapidly in the past year to more than $\$ 700$ million.

At present, forest-protection projects are not included in the carbon market used by nations to satisfy their emissions pledges under the Kyoto Protocol. This 'regulatory market' has stricter standards, and carbon on it trades for about double the price of carbon on the voluntary market.

Some nations with rainforests are pushing to include forest-protection projects in a new climate treaty, which is expected to be signed in Copenhagen in December. That would allow developing nations to

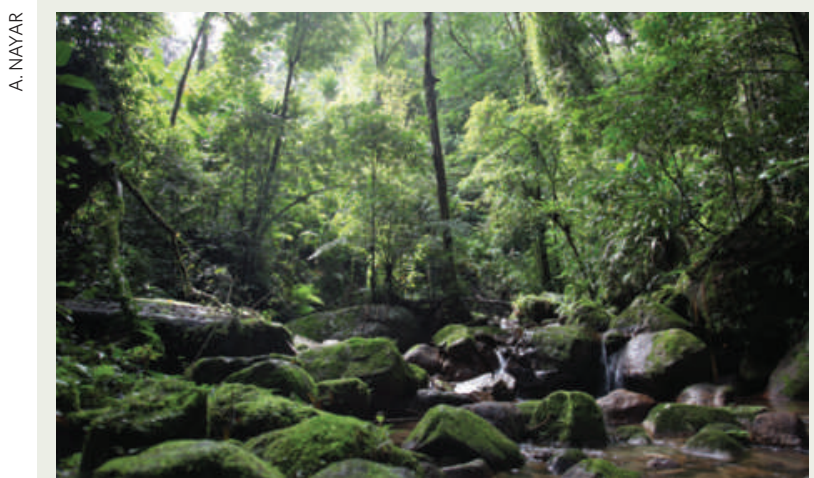

access the more lucrative carbon market for their forest programmes.

For now, the voluntary market, and the forest projects it includes, serve as a testing ground for methodologies and practices, says Janson-Smith.

For example, within the past year, organizations have developed Voluntary Carbon Standards (VCS) certification for forest-protection projects. These standards contain provisions to guard against the possibility that fires, disease or logging might destroy the protected trees

This works by requiring that forest projects keep a buffer; they can sell only a fraction of the carbon they actually store. The buffer depends on an assessment of the project's risk. "In some cases the buffer may be as low as $20 \%$ of the carbon stocks, in other cases it may be 40-50\%," says Ray Victurine, the director of the Wildlife Conservation Society's conservation finance programme. The buffer credits from the VCS-certified projects will be pooled together as an insurance policy if one or more of the projects fail. people competing for the same land. Bit by bit, the forested slopes around the village have been stripped away to plant rice and cassava. When the Makira project reached Andaparaty in 2004, Barnety supported it. "Our lives depend on the forests," he says. "If there aren't any forests, if there isn't any land, we can't live."

But without a sustainable source of income and food, some villagers are finding it difficult to accept restrictions on their access to the forest. "People are frustrated because before the project, they were completely free to hunt, fish and cut down the forests," says Cressant Rakotomanga, president of the local community organization.

It could be years before carbon payouts come through a UN-regulated REDD system. The WCS and its donors have already spent $\$ 1.9$ million to establish the Makira REDD project, and the support going to local communities will increase when the carbon funds arrive. But for the people of Andaparaty, the support can't come soon enough. "People are wondering where the money from REDD is, or if it will ever come," says Ratelolahy.

Political unrest in Madagascar makes the future of REDD projects there even less certain. On 17 March this year, following two months of protest, the 35-year-old mayor of Antananarivo, Andry Rajoelina, took the presidency in a military-backed coup.

The ensuing political instability caused a surge in illegal wildlife trafficking, mining and logging activities, threatening the country's forests. "Because of the political instability, people feel liberated, which translates to more exploiting," says Haja Salava, the director of Masoala National Park, adjacent to Makira.

Armed gangs are ravaging the northeastern region for its valuable rosewood and ebony. The park rangers and community members who have tried to impede the illegal trade have been threatened with death, says Salava.

In the past few months, thousands of illegal loggers have been raiding his national park, Salava estimates. In his dilapidated office in the regional capital Maroantsetra, he scrolls through his monthly reports to the government. The pages are a collage of photos of men posing with freshly cut wood. The loggers aren't afraid of being caught because, despite Salava's repeated calls for assistance, the government police do not stop the trade, he says. "It's a free-for-all."

Mariot Rakotovao, who led the country's Ministry of the Environment and Forests at the time, said his department had ramped up police patrols in the region and had fined illegal loggers.

But the Missouri Botanical Garden, which has been following the illegal timber trade, estimates that more than 850 shipping 


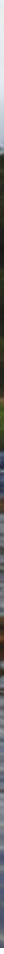

Proceeds from carbon sales could help villagers from Andaparaty, on the edge of Makira forest.

containers of rosewood have left the country since January, when the political problems began. Almost all of the exported wood was from illegal logging, says Porter Lowry of the Missouri Botanical Garden, which has conservation programmes in Madagascar.

The environment ministry did not respond to requests from Nature for comment. A government official, who asked not to be named, challenged the claim about such shipments. "That's a lot of wood. I don't believe it," he says.

\section{Wood for sale}

Other details of the timber trade are more certain. On 21 September, the government issued an inter-ministerial order allowing another wave of timber exports. The new shipments would have a combined value of tens of millions of dollars. According to the ministerial order, the shipments are designed to empty the stockpiles of timber in the country's ports and are limited in number to discourage operators from returning to the forest to cut more precious wood.

The order also stipulates that taxes on the exports will raise money for the central treasury and for forest conservation through a new fund called Action against the Degradation of the Environment and Forests (ADEF).

Jean Roger Rakotoarijaona, chair of the REDD technical committee that is putting together the country's national strategy, says legitimizing the exports of illegally felled wood

will only propagate more cutting in Madagascar. He also questions the purpose of the new forest fund. "We already have a national forest fund that needs replenishment," he says. Regarding the new fund, he says, "I'm a little worried about what this is going to be used for".

The ongoing illegal felling of trees could lead to a lot of extra carbon emissions. But even worse for Madagascar's REDD projects, the country's political instability has caused international donors to cut funding for forest and development programmes.

In March, the World Bank's Forest Carbon Partnership Facility froze a $\$ 200,000$ grant supporting Madagascar's work preparing a national REDD strategy. That delay imperils Madagascar's chances of winning a follow-up \$3.6-million grant to implement the plan, says Rakotoarijaona.

The environment and forests ministry also lost about $95 \%$ of its funding, which had come from international donors, says Rakotovao.

"Because of the instability people feel more liberated, which translates into more exploiting."

- Haja Salava

The cuts have severely impeded the ministry's ability to manage and patrol the country's forests, he says.

Investments in the country's carbon-credit projects have also stalled. The World Bank's BioCarbon Fund put a hold on its initial payment to buy offsets for 1.5 million tonnes of $\mathrm{CO}_{2}$ emissions from one of Conservation International's REDD and reforestation projects in eastern Madagascar.

The loss of funding for development projects that provide rural communities with alternative livelihoods also means more people are returning to slash-and-burn agriculture. "The short-term pillaging of forests is a problem, but slash-and-burn agriculture is the worst poverty trap," says Hawkins. "In Madagascar, it leads to the permanent loss of forests - you can't dig yourself out of that."

In the past few months, pressure from the international community forced Rajoelina into power-sharing talks with the country's three former governments. The aim is to bring about elections before the end of next year. But even if the political situation stabilizes and investors come back, there is a long road ahead to get REDD working in the towns bordering Makira.

The WCS is running workshops to teach villagers how to increase their crop production. But few people have adopted the improvements, says Jean Jaonary, the local community organization president in the village of Ambodivoahangy, on the northeast side of Makira. "Using the new method, my rice production has doubled," he says, while wading through the neat rows of his lime-green fields. "I don't know why other people haven't caught on."

As Jaonary walks through Ambodivoahangy's rice fields with Ratelolahy, women and men are busy with work, their straw hats popping in and out of the greenery. Ratelolahy says the land is all the rural populations have, and they are weary of new ways of farming and efforts to keep them out of the forest. He has faith that REDD can help these communities, but it will take time to convince each of the villagers to change. Looking towards the future, Ratelolahy summons up an old Malagasy saying: "Cows don't all wake up at the same time."

Anjali Nayar is an International Development Research Centre Fellow at Nature.

See Editorial, page 11. Watch an audio slideshow at go.nature.com/VGGayN 